Vol. 7, No. 1, 2021

${ }^{I}$ Illia Lytvynchuk, ${ }^{2}$ Oleh Rybchynskyi

\title{
TYPOLOGICAL FEATURES AND PROBLEMS OF PRESERVING URBAN DEFENSE COMPLEXES OF PRIVATE CITIES OF THE PRINCES OF ZBARAZH IN PODILLIA, KYIV REGION AND VOLHYN IN THE XVI-XVII CENTURIES
}

\author{
${ }^{1}$ Post Graduate Student of the Department of Architecture and Restoration \\ Institute of Architecture and Design \\ Lviv Polytechnic National University, Lviv \\ e-mail: illia.v.lytvynchuk@1pnu.ua \\ orcid: 0000-0002-4635-060X \\ ${ }^{2}$ Sc.Dr., Professor of the Department of Architecture and Restoration \\ Institute of Architecture and Design \\ Lviv Polytechnic National University, Lviv \\ e-mail: zoroleh@gmail.com \\ orcid: 0000-0001-9936-6122
}

Received: 11.01.2021 / Revised: 27.03.2021/ Accepted: 10.04.2021

(C) Lytvynchuk I., Rybchynskyi O., 2020

https://doi.org/10.23939/as2021.01.078

Astract. The authors of the article focus on the urban activities of the princes of Zbarazh of the senior branch. Special attention is paid to cities whose location and fortification are directly associated with representatives of the princely family. An attempt is made to find the principle that guided the Princes when choosing the city and choosing the method of fortifications. A representative sample of cities is formed, which clearly shows the dependence of the natural location, chronological boundaries of the location and the type of fortifications, based on which three types of fortified cities of Zbarazh are distinguished. In the second part of the article, the authors analyze the state of preservation of cities and give recommendations for preserving the remnants of urban defence complexes.

Key words: Janusz Zbarazky, Jerzy Zbarazky, Krzystof Zbarazky, Pryluka, Zbarazh, Nemyriv, Ladyzhyn, city fortifications, castle, fortifications, Pohrebyshche, Ozhygivtsi

\section{Problem statement}

The period between the Union of Lublin in 1659 and the National Liberation War under the leadership of Bohdan Khmelnytskyi for the border Ukrainian lands was a period of active urbanization, which was introduced by well-known magnate families, in particular, the princes of Zbarazh (coat of arms of Korybut). After the disappearance of the younger branches, all the estates of the family gathered in the hands of Janusz (Ivan) Zbarazky (before 1553-1608) and his sons Jerzy (1573-1631) and Krzystof Zbarazky (1580-1627). Historical information about the possessions of the 
Zbarazky on the border outskirts of the Polish-Lithuanian Commonwealth actively began to be published only in the 2000s. It makes it possible to identify common patterns in the strategy and tactics of defence of their cities by the Zbarazhsky using comparative analysis. It should be noted that the presence of fortifications in the cities of the steppe border was a vital necessity for their existence and directly affected the urban planning structure, so it is advisable to consider such fortifications as an independent subject of research. The vast majority of localities developed by Zbarazky do not have the status of a historical locality, which complicates the issue of preserving their historical environment. At the time of publication of the article, an attempt is being made to develop historical and architectural reference plans for the cities Nemyriv of the Vinnytsia region and Yampil of the Khmelnytskyi region, but due to an imperfectly developed historical and urban planning analysis and insufficient development of the source base, these plans have not yet been approved.

\section{Analysis of recent research and publications}

Thorough and interdisciplinary research on the topic of this article has not been conducted. In the case of most of the cities mentioned in the article, only local history essays of the XIX - early XX centuries are available (Yu. Sitsinskyi (1901), Huldman (1901), O. Orlovskyi, L. Pohylevych (1864), who at the time of their research did not yet know about the belonging of these cities to the princes of Zbarazh). Archaeological research on the fortifications of Podillia and the Kyiv region was carried out by $\mathrm{V}$. Antonovych (1895). The first attempt to comprehensively show the topic of fortification activities of the princes of Zbarazh in Ukraine belongs to O. Malchenko (2001). M. Krykun (2008 a; 2008 b) significantly complements the picture of economic and social development of the estates of the Zbarazky. The Polish researcher Z. Anusik dedicated a separate publication on the issue of latifundia of princes Zbarazki (Anusik, 2009). Prof. P. Rychkov researched the history of urban planning of individual settlements of the princes of Zbarazh (Nemyriv (2014), Ladyzhyn (2016)) based on the plans of the XVIII century found by him. An interesting finding in the history of mapping the city of Nemyriv belongs to Ya. Matviishyn (2013), who found the plan of this city in the collection of plans of the first part of the XVIII century in the archive of the Maritime Service of France and dated it 1711. The foundations of the methodological base from urban studios of historical fortified cities of Ukraine were laid by PhD S. Kravtsov, PhD P. Rychkov, PhD M. Bevz, PhD O. Rybchynskyi.

\section{Purpose of the article}

The article aims to analyze the urban defence complexes of private cities of the princes of Zbarazh, laid down in the second half of XVI - beginning of XVII century, to identify and systematize common features, to characterize the state of preservation of relics of defence complexes.

\section{Research methodology}

Based on the sources developed by historians (Malchenko, Krykun), a list of urban settlements of the princes of Zbarazh in the Bratslav, Volyn, Podillia and Kyiv voivodeships has been previously formed. A map of the policy of military colonization of the princes of Zbarazh has been compiled (Fig. 1). During the analysis of the source database, the most promising cities for research were identified. At the same time, the state of preservation of the planning structure of historical cities, ramparts and castles, the availability of cartographic material, front full-scale or archaeological surveys were taken into account. The article examines the cities that were founded by representatives of the so-called "senior" branch of the princes of Zbarazh. 


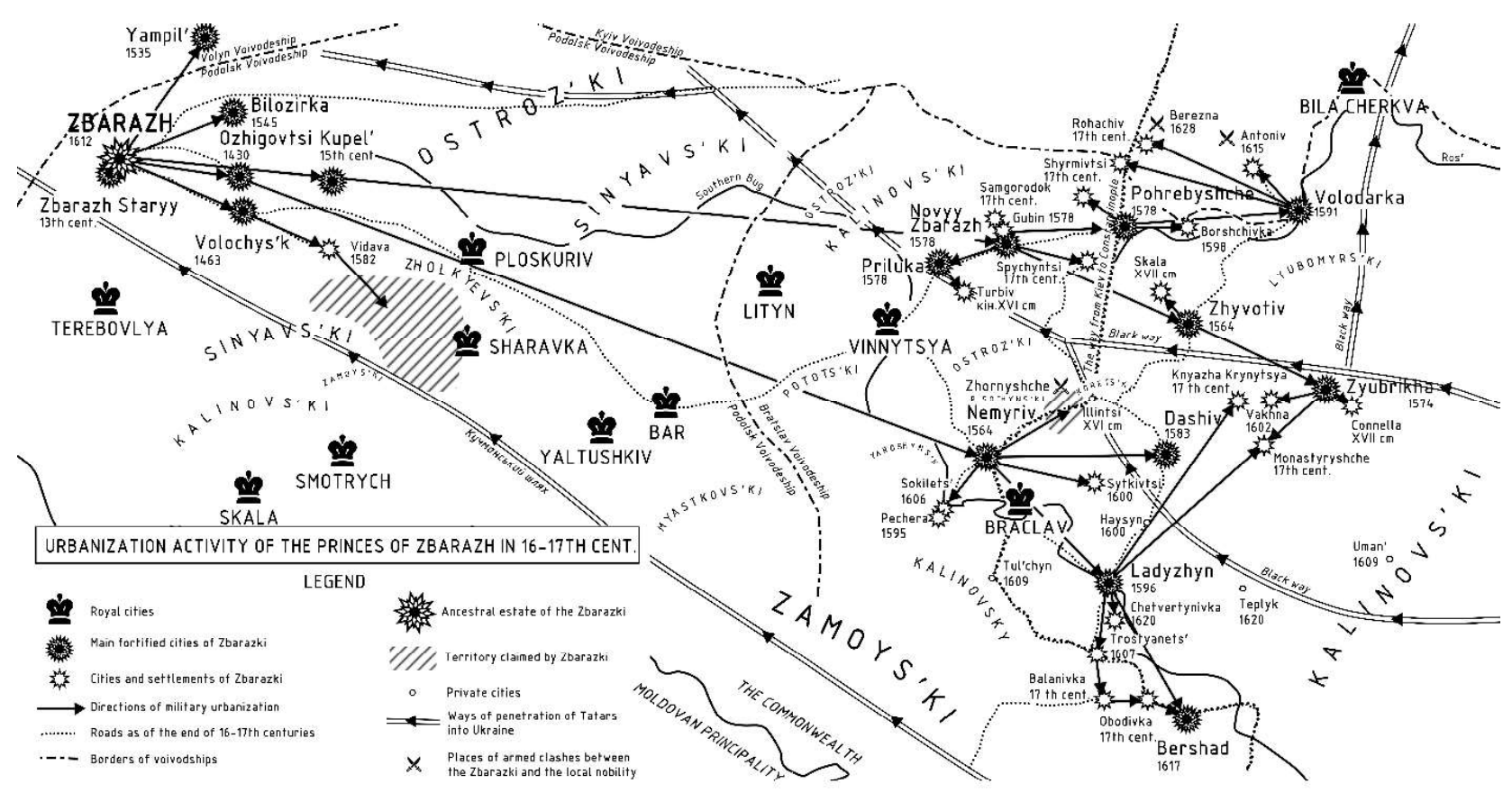

Fig. 1. Urbanization activity of the princes of Zbarazh (senior branch) at the end of the XVI-XVII century

To determine the historical planning structure of cities, a reconciliation of cartographic sources was used, such as the modern geodetic background of the city and space aerial plans, a two-door map of the General Staff of the Red Army of the interwar period (survey of the 1910s), a three-door map of Schubert (survey of the $1860 \mathrm{~s}-1870 \mathrm{~s}$ ), individual city plans. City plans of the late XVIII century are quite accurate. They are subject to reconciliation with the modern background by superimposing, for which the QGIS program was used. In other cases, only the interpretation of the cartographic source is possible using "reference" objects based on visual observation for comparison. The next stage is the localization of the main elements of the city: the market square, the sacred frame, the roads, the castle and the borders of the city centre. These elements, in turn, are already linked to defensive structures - gates to places of slingshots, city fortifications - to the borders of the city centre. Detailing fortifications during reconstruction modelling is carried out using narrative or act sources. These are the travel diaries of travellers Pavlo Alepsky (Alepsky, 1897) Ulrich von Werdum (Liske, 1876), Yulia Yusta (1899), as well as local history material collected in Podillia by Sitsynsky, Orlovsky, Huldman, and Pohylevich in the Kyiv region.

After performing reconstructions based on the most precisely developed ones, common features are identified and analyzed. The natural conditions that influenced the choice of the city's location and the method of fortification (the system of interaction between castle and city fortifications, their nature), the time of construction of fortifications were analyzed.

\section{Research results}

The Zbarazkys' urbanization and military activities in Right-Bank Ukraine can be divided into two periods. The first period associated with the activities of Ivan (Janusz) Zbarazky (1574-1608) is characterized by the active acquisition of landholdings and the foundation of new cities on the site of the acquired villages (Nemyriv, Zbarazh Novyi, Hubyn, Sokilets). The second period is associated with the sons of Janusz-Krzystof and Jerzy Zbarazhsky - they continue to increase the family's estates in the region and, most significantly, there is a fortification of cities according to new engineering trends (Zbarazh, Bershad, Ladyzhyn). In fact, the beginning of this stage can be 
considered the acquaintance and communication of Krzystof Zbarazky with the military engineer Tomasz Zamoyskyi - Andrea del Aqua in 1602. At that time, Krzystof had already mastered the science of fortification and could offer his own view on the method of strengthening the new ancestral castle in Zbarazh, which allows us to assume his authorship in all the modern fortifications of the XVII century that belonged to the Zbarazh family. In 1608, Janusz died and the brothers Jerzy and Krzysztof became full owners of fortified private cities of their kind.

Prince Janush inherited his first estates from his father Nikolai Zbarazky - Staryi Zbarazh - family nest, Ozhehovtsi, Brahyn, Yanushpol. A part of them he received for the wife Princess Anna Chetvertynska - Zhivotiv, Nemyriv, Pryluky, Pohrebyshche. In 1579-1607 the prince is actively buying up estates from small local gentry: from Prylutsky he buys Pryluka and Pohrebyshche in 1574; from Sedansky he buys Dashev in 1585; from Trembytsky - Borshchivka in 1589, from Zahorovsky - Volodarka in 1595, from Korotky - Ladyzhyn in 1594. He tried to forcibly annex the Zhornyshcha estate to his possessions in order to connect his possessions of the Nemyrivsky and Pohrebyshchensky parts, as a result of which a long-term armed conflict unfolded with the owner of this estate, Pisochynsky (Krykun, 2008, pp. 121156). Krzystof and Jerzy Zbarazky in the XVII century continued military colonization to the south and laid the cities of Obodovka, Balanivka, Bershad, took part of the lands of the Belotserkov burghers and founded the cities of Antonov and Berezna on their lands.

The defence of fortified cities began with the choice of the optimal terrain. The princes of Zbarazh were among those who used the natural topography the most. In the cases of Nemyriv, Ozhyhivtsy and Pryluky, the following common features are clearly distinguished: the location of the defensive castle at the end of the peninsula, surrounded by a pond on three sides, the strengthening of the city on the floor side by ramparts of an arc configuration. In the case of Nemyrov, the fortifications are a pair of ramparts $1.4 \mathrm{~km}$ long (the unpublished plan of Nemyriv and the surrounding area). Such a huge length was not typical of either medieval or early modern cities due to the inability to gather the necessary number of professional soldiers for defence. That is why we assume that these ramparts have an ancient origin and are reused to defend the city from the Tatars - cartography and narrative sources of the XVIII century (Yul, Rusov, 1876, p. 33) do not reflect data on any modernization of these fortifications for long-term defence against regular troops. The defensive belt of Ozhehovtsi is much more modest, its perimeter reaches about $500 \mathrm{~m}$ (Fig. 3). Relics of defensive fortifications of the Russian-Lithuanian era are observed in Janushpol and Pohrebyshche (Fig. 2), it is also known that at the time of their purchase by Zbarazky, they were already cities. As for the cities founded or built and equipped by Jerzy and Krzystof, there is a different trend in them - the location of the city centre is in the corner between two ponds, as well as the castle and city fortifications are separated by a pond or lake. This principle is most clearly traced in Zbarazh, Ladyzhyn, Bershad, and partly in Balanivka (where the castle was probably located in the system of fortifications of the city centre and occupied a place near the connections of two ponds). Ladyzhyn, however, had its own special feature - instead of the second pond, the channel of the full-flowing Pivdennyi Buh river was used, to which the Silnytsia river flowed, on which, in turn, a pond was already built with the help of a dam. There is an interesting location of the village of Vydava, which is also located between two ponds. However the development of Vydava does not show an urban character, and there is also no confirmation of the existence of this locality as a fortified city in the acts. Vydava was acquired by Janusz Zbarazky, probably as a promising fortified key city, since the Zbarazky claimed the territory south of Vydava and Medvedivka and they needed the administrative centre of the future estate key here.

The system of artificial ponds through the construction of dams was inherent in cities of both categories. It increased the defence capability of cities during the warm period when cities were subjected to the most numerous attacks by the Tatars. In addition to the construction of ponds, artificial channels were also dug for wet ditches. Such a canal was dug in Zhyvotiv (called "fosa" by the local population), the canal connecting the moat of the Ladyzhyn city fortifications with the Silnytsia river can be traced in 
the plan of 1849 (Rychkov, 2016). An artificial moat can be seen in the cellars that separated the castle Promontory from the city, and the two-verst map shows an artificial channel, which probably formed the wet moat of the city itself.

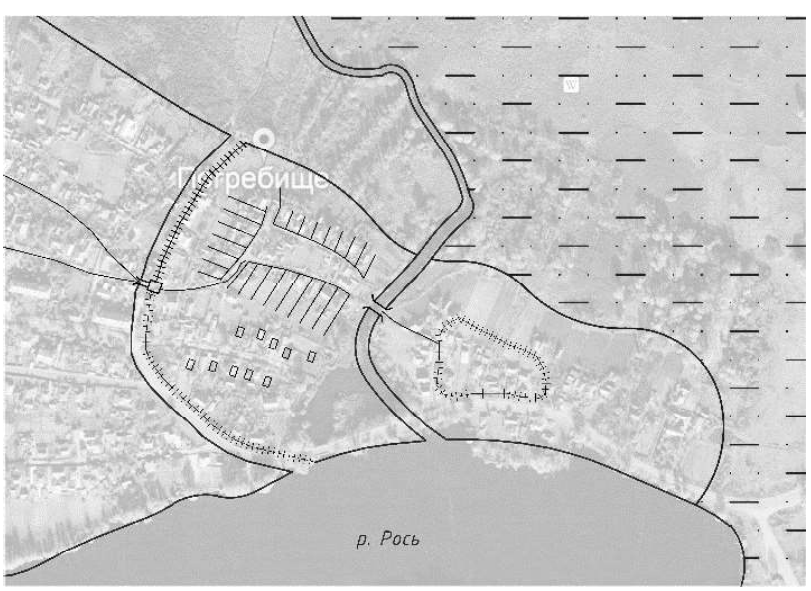

Fig. 2. Reconstruction of the urban defence complex in Pohrebyshche (author's study)

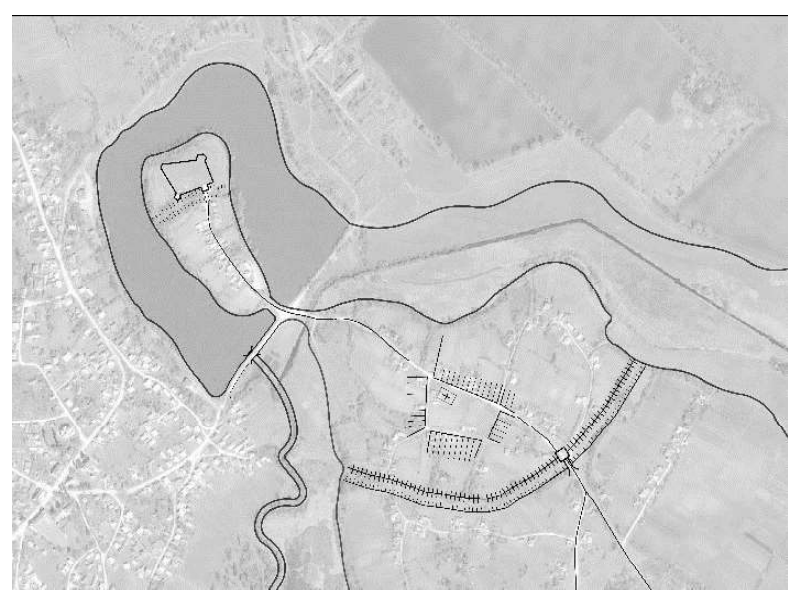

Fig. 3. Reconstruction of the urban defence complex in Ozhyhivtsi (author's study)

A regular market square in the form of a square or rectangle can be considered a sign of cities laid out by Zbarazky (a new location). There are such squares in Zbarazh, Nemyriv, Ladyzhyn, Bershad. In cities that existed at the time of their acquisition by Zbarazhsky, market squares have an irregular configuration, characteristic of cities on Rus law (Yanushpol, Zhyvotiv, Pohrebyshche).

\section{Typology of fortified cities of Zbarazki}

\begin{tabular}{|l|l|l|l|}
\hline Development period & $\begin{array}{c}\text { Location } \\
\text { according to } \\
\text { natural } \\
\text { conditions }\end{array}$ & $\begin{array}{c}\text { Nature of castle } \\
\text { and city } \\
\text { fortifications }\end{array}$ \\
\hline $\begin{array}{l}\text { 1. Cities founded } \\
\text { before purchasing } \\
\text { by Zbarazky } \\
\text { (before 1579) }\end{array}$ & $\begin{array}{l}\text { In a swampy } \\
\text { plain }\end{array}$ & $\begin{array}{l}\text { Ancient Rus } \\
\text { Prince Ya. Zbarazky } \\
\text { (1579-1602) }\end{array}$ \\
\hline $\begin{array}{l}\text { 3. Cities founded or } \\
\text { built by Krzystof } \\
\text { and Jerzy Zbarazky } \\
\text { (1602-1631) }\end{array}$
\end{tabular}

Factors of the destruction of defence complexes

Due to the powerful development of artillery in the second half of the XVII century, medieval and early modern urban defence complexes lose their relevance and gradually disappear due to the 
transformation of fortified cities, depending on their status in modern times. It is possible to distinguish two essentially opposite types of transformations of the space of a historical fortified city, which led to the loss of defensive complexes. The first one is redevelopment according to regulatory principles. This trend can be traced to the XVIII-XX centuries in several periods. The first redevelopment actions were introduced by Polish heirs of private settlements under the influence of the prevailing in Europe trends of classicism in the second half of the XVIII century. It was under this influence Stanislav Potocki reconstructed Nemyriv. Cartographic sources from 1711-1789 show that classical planning was implemented around the already existing Renaissance Market Square and central quarters. The outskirts of the city with its city fortifications went under construction - on the plans of the end of the XVIII century only a fragment of the outer shaft is fixed. The hypodam network of streets set inertia for the further development of the city already in the XIX century, when the city's defensive structures were finally destroyed. We assume that the same story was with Bershad, which relics of the city's defensive structures can not be traced, too.

At the beginning of the XIX century, the second period of alterations took place and mass redevelopment of Ukrainian historical cities that have just entered the Russian Empire. The imperial authorities used classicism in urban planning as a marker of their presence in the newly acquired territories, which then became a visual embodiment of the ideas of an absolutist monarchy. First of all, administrative centres - county and provincial cities, as well as military settlements created in the period between 1817 and 1850 - were subject to redevelopment. One of these military settlements was established in Ladyzhyn after its confiscation from the landowner Sobansky as a result of his participation in the Polish uprising. Redevelopment of the city was carried out in 1843 (project) and implemented - the city plan of 1849 fixes the regulation that still exists today. Redevelopment captured the outskirts of the city centre (especially the southern part) and two suburbs, which were fortified "in the Cossack way" (according to W. Von Werdum). Nevertheless, in the central part, the historical market square and parcel blocks have been preserved since the XVII century, which makes it possible to make a reasonable theoretical reconstruction of the city as of this period.

Some cities were redeveloped in the twentieth century with the destruction of all the relics of ancient defensive complexes among them - Monastyryshche and Volodarka. In the 1960s, the construction of a bus station destroyed an archaeological monument that had previously been taken on state registration the ancient settlement of the so-called "Cossack fortress" in Bershad (State Archive of Volyn Region, fond 4971/1/40, pp. 41-42). In our opinion, this fortress was the Zbarazhsky Castle, located on the opposite bank of the Berlandinka river, it was separated from the city by an artificially created pond on this river like Zbarazh and Ladyzhyn.

Another sscenario that also leads to the loss of the urban planning structure of urban defence complexes is the degradation of a locality, which is associated with a gradual decrease in its administrative status. All the fortified localities shown on the Boplan map were cities in the XVII century. Some of them became towns in the XVIII century, and then they became villages in the XX century. As a result, the dense urban development of the city centre (in populated areas) was replaced by a rural estate with the loss of the original parcel and entire city streets. So, today it is not possible to reprimand the authentic planning system of the former Novyi Zbarazh (Zbarazh, Vinnytsia region) and other localities (Zhubrykha, Vakhna, Knyazha Krynytsa and others).

In Balanivka, Obodovka and Pryluka, both scenarios were combined. At the beginning of the twentieth century, the owner of these settlements, which were then in the status of towns, achieved the abolition of this status and their transfer to rural settlements (Orlovskyi, 1869). Since the beginning of the XIX century, the centres of the towns were inhabited mainly by Jews, and Jews were not allowed to live in the villages, Jews were resettled and the centre was demolished. In their place, landscape and park complexes with the landowner's estates were arranged. Nevertheless, the buildings at the suburbs (along 
the line of city fortifications) remained and today it is possible to establish an approximate outline of the fortifications of the cities of Pryluky and Balanivka.

The best state of preservation of urban defence complexes is present in Zbarazh and Ozhegovtsy. Zbarazh has retained its urban status and avoided redevelopment, as a result of which the planning system of the city centre is quite stable. The outline of urban fortifications can be seen in cadastral prints. The castle fortifications are completely preserved, including the second line of earthen bastion fortifications. Ozhyhivtsy became a village in 1923. The planning structure of the city centre is preserved as well as the ramparts of the city fortifications. At the level of archaeological objects (still not registered), a paired ancient settlement with a castle in Stara Pryluka, city ramparts in Ozhegovtsy and Ladyzhyn have been preserved.

None of the cities considered in the article at the time of its publication has a valid historical and architectural reference plan approved by the Ministry of Culture of Ukraine as part of the general plan of the locality. Nowadays only careful development of a historical and architectural reference plan with a correct reflection of the stages of Urban Development and identified relics of ancient planning and defensive structures, as well as developed based on historical and urban planning studies of protection zones and their regulations can give a chance to preserve the historical space of fortified cities of the XVI-XVII centuries and open the way to its regeneration.

However, it should be noted that the existing regulatory framework does not allow to preserve the entire defence complex as a single object of cultural heritage, since its components according to the current legislation contain signs of certain categories of cultural heritage monuments - preserved fortifications - as archaeological monuments, artificially changed landscape - ponds and lakes - are not subject to protection, if not related to a natural monument, the planning structure of a fortified city - as a historical area (if in addition to the planning system, historical buildings are also preserved and there are cultural heritage monuments). So it is necessary to develop and implement new approaches that will allow you to take under state protection urbanistic defence complexes of historical cities as a whole.

\section{Conclusions}

There are three main types of fortified cities in Zbarazh. Their landing on the ground and planning characteristics correlate with the periods of urban development: cities of the first type, which were built in the XV-XVI centuries located in swampy plains and have features of Ancient Rus planning; cities of the second type are laid down by Janusz Zbarazky in the second half of the XVI century use the meander of rivers and peninsulas for the location of castles, do not have modernized fortifications for artillery; cities of the third type are located between two ponds, have modern fortifications for their time, the castle is separated from the city by a reservoir.

The lack of modernization of fortifications under the principles of using artillery of the XVII century indicates countering small but frequent Tatar attacks as the main priority in defensive tactics.

The best preservation of the historical planning structure and relics of defence complexes can be traced in localities that have not lost their urban status (except the cities with intensive processes of urbanization and regulation at the end of the XVIII-XX century).

It is necessary to improve the regulatory and legislative framework for preserving the historical environment of former fortified cities at least at the level of planning structure since the current legislation provides for the protection of territories as historical areas where historical buildings are preserved and there are listed monuments of cultural heritage, which does not exist in the case of historical fortified cities of Bratslav region. 


\title{
References
}

Antonovich, V. B., 1895. Archaeological map of the Kiev province (supplement to the XV volume of "Antiquities"). Moskva : Tipografiya M. G. Volchaninova.

Fundukley, I., 1848. Review of graves, ramparts and settlements of the Kiev province: published by the imperial permission of the Kiev civil governor Ivan Funduklei. Kiyev: Tipografiya Felfila Gliksberga.

Gul'dman, V. K., 1901. Monuments of antiquity in Podolia: materials for compiling an archaeological map of the Podolsk province. Kamenets-Podol'skiy: tipografiya Podol'skogo gubernskogo pravleniya.

Krykun, M ta Piddubnyak, M., 2008. Documents of Bratslav Voivodeship 1566-1606. L'viv : Naukove Tovarystvo imeni Shevchenka.

Krykun, M., 2008. Bratslav Voivodeship in the XVI-XVIII centuries: Articles and materials. L'viv: Vydavnytstvo Ukrayins'koho Katolyts'koho Universytetu.

Mal'chenko, O. Ye., 2001. Fortified settlements of Bratslav, Kyiv and Podil voivodships of the 15th - middle of the 17th centuries. Kyyev: Natsional'na akademiya nauk Ukrayiny, Instytut ukrayins'koyi arkheohrafiyi ta dzhereloznavstva im. M. S. Hrushevs'koho.

Matviyishyn, Ya., 2013. Kartohrafichna ukrayinika v arkhivakh Mors'koyi sluzhby Frantsiyi, Ukrayins'ke dzhereloznavstvo ta spetsial'ni istorychni dystsypliny na porozi KHKHI st. Proceedings of the International Conference dedicated to the 85th anniversary of the birth of Yaroslav Dashkevych (December 13-14, 2011, Lviv). L'viv. p. 263-291.

Pavel Aleppskiy, P., 1897. The journey of the Antiochian patriarch Macarius to Russia in the middle of the 17th century, described by his son Archdeacon Pavel Aleppsky: (Based on the manuscript of the Moscow chief architect M-va foreign affairs). Issue 2: From the Dniester to Moscow. Translated from Arabic by G. Murkos. Moskva : Obshchestvo istorii i drevnostey rosissyskikh pri Moskovskom universite.

Pokhilevich L., 1864. Legends about the populated areas of the Kiev province or Statistical, historical and church notes about all villages, villages, townships and cities located within the province. Kiyev : V tipografii Kiyevo-Pecherskoi lavry.

Rusov, A. A., 1876. Russian tracts at the end of the 17th and beginning of the 18th centuries and some data on the Dnieper from the atlas of the end of the last century. Kiyev : Tipografiya. M. P. Fritsa, Kiyev.

Rychkov, P., 2014, Nemyriv na Podilli: malovidomyy urbanistychnyy eksperymentu doby prosvitnytstva. Experience and prospects of development of cities of Ukraine. 26. S. 88-108.

Rychkov, P., 2016, Kartohrafichni dzherela do istoriyi mistobuduvannya Skhidnoho Podillya (KHVIII-KHIKH st.). Cities and towns of Podillya from the Middle Ages to the beginning of the twentieth century. Proceedings of the scientific conference on September 24-25, 2015. Vinnytsya, p. 48-85.

Setinsky, E., ed., 1901. Proceedings of the Podolsk Diocesan Historical and Statistical Committee. - Issue. 9: Parishes and churches of the Podolsk diocese. Kamyanets-Podolsk.

Yul', YU., 1899. Notes by Yust Yul, the Danish envoy under Peter the Great. 1709-1711 (1899). Translated from Danish by Yu. N. Shcherbachev. Moskva : Universitetskaya tipografiya.

\author{
${ }^{1}$ Ілля Литвинчук, ${ }^{2}$ Олег Рибчинський \\ ${ }^{1}$ Аспір. кафедри архітектури та реставраиії \\ Національного університету “Львівська політехніка”, Львів \\ e-mail: illia.v.lytvynchuk@lpnu.ua \\ orcid: 0000-0002-4635-060X \\ 2 Д-р арх., проф. кафедри архітектури та реставраиії \\ Національного університету “Львівська політехніка”, Львів \\ e-mail: zoroleh@gmail.com \\ orcid: 0000-0001-9936-6122
}

\section{ТИПОЛОГІЧНІ ОСОБЛИВОСТІ ТА ПРОБЛЕМИ ЗБЕРЕЖЕННЯ УРБАНІСТИЧНИХ ОБОРОННИХ КОМПЛЕКСІВ ПРИВАТНИХ МІСТ КНЯЗІВ ЗБАРАЗЬКИХ НА ПОДІЛЛІ, КИЇВЩИНІ ТА ВОЛИНІ У XVI-XVII ст.}

\footnotetext{
Анотація. Автори статті фокусують увагу на урбаністичній діяльності князів Збаразьких стариої гілки, чия діяльність у хронологічних межах дослідження (кін. XVI - mp. XVII cm.) розгорнулась на Східному Поділлі, у віддаленні від своїх родових маєтків родини на Волині та у Великому Князівстві Литовському. Заклавии нову резидениію Новий Збараж (с. Збараж Вінницької області), князі швидко почали укріплюватись на теренах Браилавщини та Київщини,
} 
у XVII ст. їхні маєтки сягнули польсько-татарського степового прикордоння. Особливу увагу приділено власне містам, чию локацію та фортифікування пов'язують безпосередньо з представниками княжої родини. Здійснено спробу знайти принцип, яким керувались князі при виборі міста та вибору способу укріплень. Сформовано репрезентативну вибірку міст, у який чітко прослідковується залежність природнього розташування, хронологічні межі локаиії та тип укріплень, на підставі чого виділено три типи укріплених міст Збаразьких. Виділено три категорії міст Збаразьких, які поєднуються спільними планувально-просторовими, природними та хронологічними характеристиками. Використана методика комплексного історико-містобудівного аналізу проілюстрована на гіпотетичних реконструкиіях вигляду таких міст як Погребище та Ожиговиі у кін. XVI-XVII cm. Обидва міста належсать до першої категорії міст у розробленій авторами типологї̈, які характеризуються розташуванням у багнистій місиині, використовують принципи давньоруського планування та оборони й хронологічно були закладенні XV-XVI cm.. до придбання їх князем Янушем Збаразьким. До другої категорії автори відносять міста, шо були закладені безпосередньо князем Янушем, і до третьой - міста, що розбудовувались його синами - Сжи та Киистофом. Міста останньої категорії відрізняються регулярним плануванням зі застосуванням модерних фортифікаиій, характерною особливістю яких є розділення замкових та міських фортифікаиій водоймою. У другій частині статті автори аналізують стан збереження міст та дають рекомендаиії щодо збереження залииків урбаністичних оборонних комплексів.

Ключові слова: Януи Збаразкий, Сжи Збаразкий, Кшистоф Збаразкий, Прилука, Збараж, Немирів, Ладижин, міські укріплення, замок, укріплення, Погребище, Ожигівиі 